\title{
The Impact of Financial Leverage on the Variance of Stock Returns
}

\author{
David Yechiam Aharon ${ }^{1, *}$ and Yossi Yagil ${ }^{2,3}$ \\ 1 Department of Business Administration, Ono Academic College, Haifa 55000, Israel \\ 2 Department of Business Administration, University of Haifa, Haifa 3498838, Israel; yyagil@univ.haifa.ac.il \\ 3 Department of Business Administration, Western Galilee College, Akko 2412101, Israel \\ * Correspondence: dudi.ah@ono.ac.il
}

Received: 10 January 2019; Accepted: 28 February 2019; Published: 6 March 2019

check for updates

\begin{abstract}
This paper investigates the direct theoretical relationship between the variance of stock returns $\left(\sigma^{2} \mathrm{E}\right)$ and financial leverage $(\mathrm{L})$ considering both corporate and personal taxes. Using a dataset of U.S. industrial firms, we examine the variance of stock returns as a function of the firm's financial leverage. We demonstrate that (1) the variance of stock returns is positively related to the firm's financial leverage, (2) the relationship between the variance of stock returns and financial leverage is positive when corporate and personal taxes are also considered, and (3) with regard to the relationship between the variance of stock returns and financial leverage, using market measures of the latter tends to generate a higher coefficient of determination and a more accurate approximation of the theoretical relationship between financial leverage and the variance of stock returns.
\end{abstract}

Keywords: volatility; financial leverage; market imperfections; corporate taxes; personal taxes

JEL Classification: G30; G32

\section{Introduction}

Volatility, which is commonly measured by the standard deviation of stock returns, has received a great deal of attention in the literature, as it is the key factor in portfolio theory, option valuation, and asset pricing models. Volatility is important to academics, policy makers, and financial market participants. For policy makers, a volatile stock market can be a source for concern, because the instability of the stock market creates uncertainty, which may have an adverse effect on growth prospects. In fact, volatility can be helpful for the formulation of the economic policies, rules, and regulations related to the stock market. Investors use the variance of stock returns as a measure of risk to assess the performance of their past and future investments. Also, volatility has a central role in the pricing theories of derivatives. The Black-Scholes option pricing model treats volatility as the only parameter, among the strike price, time to expiration, interest rate, and stock price that must be forecasted. Finally, academics try to identify the factors that affect the volatility of stock returns and its role in determining capital structure valuation.

While the literature is replete with studies devoted to the characteristics of the variance of stock returns (henceforth: $\sigma_{\mathrm{E}}^{2}$ or $\sigma_{\mathrm{E}}$ ), there are very few studies to the best of our knowledge on the direct relationship between financial leverage (henceforth: $\mathrm{L}$ ) and $\sigma_{\mathrm{E}}$, a fortiori when both corporate and personal taxes exist. The closest type of studies that does refer to the impact of $\mathrm{L}$ on $\sigma_{\mathrm{E}}$ is what is commonly named in the literature as "leverage effect" studies in which the impact of $\mathrm{L}$ on $\sigma_{\mathrm{E}}$ is evident only indirectly. In such studies, financial leverage is provided as a potential explanation for the asymmetric $\sigma_{\mathrm{E}}$ found under various market conditions. This possible explanation can be easily 
demonstrated based on the pioneering "leverage effect" works of Black (1976) and Christie (1982) described by Equation (1) below:

$$
\left.\sigma_{\mathrm{E}}=\Delta \mathrm{E} / \mathrm{E}=\Delta \mathrm{V} / \mathrm{E}=(\Delta \mathrm{V} / \mathrm{V}) \times(\mathrm{V} / \mathrm{E})=(\Delta \mathrm{V} / \mathrm{V}) \times[(\mathrm{E}+\mathrm{D}) / \mathrm{E})\right]=(\Delta \mathrm{V} / \mathrm{V}) \times \mathrm{L}=\sigma_{\mathrm{V}} \times(1+\mathrm{L})
$$

where $\mathrm{V}$ is the value of the firm, $\mathrm{E}$ is the value of outstanding equity, and $\mathrm{D}$ is the value of debt, so that $\mathrm{V}=\mathrm{E}+\mathrm{D}$. According to this formulation, if debt is risk-free, a change in the value of the firm's assets $(\Delta \mathrm{V})$ is passed entirely through to the equity: $\Delta \mathrm{E}=\Delta \mathrm{V}$. Thus, Equation (1) expresses the change in the value of a firm's stock caused by a given $\Delta \mathrm{V}$. Meaning, $\sigma_{\mathrm{E}}=\sigma_{\mathrm{V}}(1+L)$, where $\sigma_{\mathrm{V}}$ is the standard deviation of asset returns, and $\sigma_{\mathrm{E}}$ is the standard deviation of equity returns. An important and well documented empirical feature in many financial markets is the financial leverage effect (Black 1976; Christie 1982). According to the latter, a higher return reduces $L$ (because a positive return increases the value of the equity, while the risk free debt is unchanged) and is therefore expected to lower the volatility of equity returns. In contrast, a lower return should have the opposite effect on $\sigma_{\mathrm{E}}$. That is, an increase in $\mathrm{L}$ also increases $\sigma_{\mathrm{E}}$.

To summarize, to the best of our knowledge, the existing studies in the literature have not tested the direct theoretical relationship between $\sigma_{\mathrm{E}}$ and $\mathrm{L}$ when both corporate and personal taxes exist. The purpose of this study is to test directly whether and to what extent the theoretical relationship between $\sigma_{\mathrm{E}}$ and L established in the literature holds in the real corporate world, particularly when corporate taxes and personal taxes are considered. To overcome the potential problem of measurement errors and for the sake of a sensitivity analysis, we use both book and market measures of leverage with two methods of calculating corporate and personal taxes. Finally, we test which of the risk free debt theoretical models (the perfect capital market model, the corporate taxes only model, or the theoretical model that includes both corporate and personal taxes) best describes the real relationship between $\sigma_{\mathrm{E}}$ and L. We make this differentiation by comparing the observed parameters from the regression analysis with the theoretical values implied by each model. We contribute to the literature by employing a direct and thorough empirical test of the theoretical relationship between $\sigma_{\mathrm{E}}$ and $\mathrm{L}$. The direct test should fill a gap in the literature on capital structure theory and can assist portfolio managers, investors, and policy makers.

To emphasize, our study extends the literature in several aspects. First, we test three (rather than one) theoretical models in the context of the $\sigma_{\mathrm{E}}-\mathrm{L}$ relationship. Second, we actually compare the OLS (Ordinary Least Squares) regression coefficients in all three models with their theoretical counterparts and examine whether the differences between these values are statistically significant-an important investigation that has not been conducted so far in the literature. Third, while prior studies simply employed a standard regression analysis of the relationship between $\sigma_{\mathrm{E}}$ and $\mathrm{L}$ and some other variables, conducting what we call an indirect-test, we in contrast apply a direct test approach by testing the theoretical relationship between $\sigma_{\mathrm{E}}$ and $\mathrm{L}$ directly. In addition, we employ direct estimates of the additional variables that are present in the theoretical models, such as corporate and personal taxes, and we also use both book and market leverage measures.

This paper is organized as follows. Section 2 provides a detailed scientific background of both theoretical and empirical studies of the relationship between $\sigma_{\mathrm{E}}$ and L. Section 3 presents the main hypotheses and the methodology. In Section 4, we describe the sample, the selection process, and data sources used for the construction of the sample. Section 5 discusses the empirical results, while Section 6 concludes.

\section{Scientific Background}

Many of the recent studies about financial leverage $(\mathrm{L})$ and volatility $\left(\sigma_{\mathrm{E}}\right)$ introduce the leverage effect hypothesis, which posits that stock returns and volatility are negatively correlated. One explanation for the negative relationship is that an increase in volatility leads to an increase in the expected return on the equity, which results in a decline in stock prices. An alternative explanation is 
referred to financial leverage, where a drop in stock prices leads to an increase in financial leverage, resulting in an increase in the volatility of stock returns.

Using a sample of 30 stocks, mostly Dow Jones Industrials, from 1964 to 1975, Black (1976) was the first to demonstrate the so-called leverage effect in the context of asymmetric equity volatility. He showed that stock volatility was negatively correlated with stock returns, meaning that volatility tends to grow as stock prices drop. He argues that a possible explanation for the negative relationship is due to a financial leverage effect, meaning when stock prices fall, financial leverage increases, leading to an increase in the volatility of stock returns. He also states that a similar effect may occur even if the firm has almost no debt because of the presence of so-called "operating leverage" (fixed costs that cannot be eliminated, at least in the short run). Therefore, a stylized fact is that financial leverage may be the factor accounting for this negative relationship. However, the empirical evidence for this effect is not conclusive. Moreover, crises, such as the 2008 subprime crisis (which is a debt crisis), may call for another reconsideration of the leverage effect discussed in the literature. On the one hand, in this subprime crisis, stock prices actually fell, leading to a higher financial leverage, but on the other hand, the crisis itself was a debt crisis, which caused a crash in bond prices, causing the opposite effect on the financial leverage. From this viewpoint, this study is motivated to test the direct $\sigma \mathrm{E}-\mathrm{L}$ relationship to investigate the true effect of financial leverage.

Early studies, such as those of Christie (1982), Cheung and Ng (1992), and Duffee (1995), found that volatility seems to rise when stock prices go down and decline when stock prices go up. Schwert (1990) showed that stock market volatility increases during recessions and after a large drop in stock prices. He found that the higher the financial leverage of the market, the greater the volatility. Figlewski and Wang (2000) noted a strong leverage effect for falling stock prices, but for positive returns they found a very weak or even non-existent leverage effect. They called these findings the "down market effect", because it is much stronger when the market is falling. Titman and Wessels (1988) reported a negative association between earnings volatility and leverage. Lemmon et al. (2008) found a negative effect of cash flow volatility (measured by the standard deviation of historical operating income) on the leverage decisions of firms. Bollerslev et al. (2012) established a negative correlation between volatility and current and lagged returns, which lasts for several days, weak correlations between the returns and the lagged volatility, and strong correlations between high frequency returns and their absolute values. Their findings support the dual presence of a prolonged leverage effect at the intra-daily level and an almost instantaneous volatility feedback effect. Ait-Sahalia et al. (2013) used a natural estimate of the empirical correlation between daily returns and changes in daily volatility estimated from high frequency data. Using the well-known Heston model, they found that at high frequencies and over short horizons, the estimated "leverage parameter" is close to zero instead of being an expected strong negative value. At longer horizons, the effect is present, especially when using option-implied volatility. The authors also provided theoretical results to disentangle the biases involved in estimating the leverage parameter and isolated the sources one by one: Discretization bias, smoothing bias, estimation error, and noise correction error. In addition, they also considered the influence of price jumps on estimating the correlation between Brownian shocks to price and volatility. Using a simulation study, they successfully recovered the leverage parameter using a simple OLS regression.

To summarize, while there are numerous indirect studies that connect financial leverage with the volatility of stock returns, this study is motivated to test the direct effect of $L$ on $\sigma_{\mathrm{E}}$. To the best of our knowledge, this is the first study that implements in this manner such a test.

\section{Theory, Hypotheses, and Methodology}

Based on Modigliani and Miller $(1958,1963)$ capital structure theory, the standard deviation of equity returns $\left(\sigma_{E}\right)$ is a function of the financial leverage of the firm $(\mathrm{L})$ and the specific market imperfections considered. To derive the $\sigma_{\mathrm{E}}$ expressions, we first present the formulations for the required return on equity $\left(\mathrm{K}_{\mathrm{E}}\right)$. Yagil (1982) devised a general theoretical expression to describe $\mathrm{K}_{\mathrm{E}}$ as 
a function of the required return for an unlevered firm, the firm's financial leverage, the corporate and personal tax rates, and when debt is also risky and associated with bankruptcy costs:

$$
\mathrm{K}_{\mathrm{E}}=\mathrm{K}_{\mathrm{U}}+\left[\mathrm{K}_{\mathrm{U}}\left[(1-\Psi)-\mathrm{r}\left(1-\mathrm{T}_{\mathrm{C}}\right)\left(1-\mathrm{T}_{\mathrm{E}}\right)\right] \mathrm{L},\right.
$$

where $\mathrm{K}_{\mathrm{E}}$ is the required return on equity for the levered firm, $\mathrm{K}_{\mathrm{U}}$ is $\mathrm{t}$ required return on equity for the unlevered firm, $\Psi$ equals $(1-q-T)$, where $q$ is the bankruptcy factor as a percentage of the firm's debt, $\mathrm{T}$ is the tax ratio given by the term $\left(1-\mathrm{T}_{\mathrm{C}}\right)\left(1-\mathrm{T}_{\mathrm{E}}\right) /\left(1-\mathrm{T}_{\mathrm{D}}\right), \mathrm{T}_{\mathrm{C}}$ is the corporate tax rate, $\mathrm{T}_{\mathrm{E}}$ is the personal tax rate applicable to equity holders, $T_{D}$ is the personal tax rate for debt holders, $r$ is the required return on debt, and $\mathrm{L}$ is the financial leverage ratio of the firm given by $\mathrm{D} / \mathrm{E}$ where $\mathrm{D}$ and $\mathrm{E}$ are the values of the debt and equity, respectively ${ }^{1}$.

If capital markets are perfect, and debt is risk free, and neither corporate nor personal taxes exist, then $\Psi=0$ and Equation (2) reduces down to:

$$
\mathrm{K}_{\mathrm{E}}=\mathrm{K}_{\mathrm{U}}+\left[\left(\mathrm{K}_{\mathrm{U}}-\mathrm{r}\right) \mathrm{L}\right]
$$

which is similar to Modigliani and Miller's proposition 2 for the cost of equity in the absence of taxes.

If debt is risk free and corporate taxes are the only market imperfection, then $\Psi$ from Equation (2) is reduced down to: $\left[1-\left(1-\mathrm{T}_{\mathrm{C}}\right)\right]$ or simply $\mathrm{T}_{\mathrm{C}}$ and the resulting relationship becomes:

$$
\mathrm{K}_{\mathrm{E}}=\mathrm{K}_{\mathrm{U}}+\left[\mathrm{K}_{\mathrm{U}}\left(1-\mathrm{T}_{\mathrm{C}}\right)-\mathrm{r}\left(1-\mathrm{T}_{\mathrm{C}}\right)\right] \mathrm{L},
$$

which can also be organized as:

$$
\mathrm{K}_{\mathrm{E}}=\mathrm{K}_{\mathrm{U}}+\left(1-\mathrm{T}_{\mathrm{C}}\right)\left(\mathrm{K}_{\mathrm{U}}-\mathrm{r}\right) \mathrm{L},
$$

where Equation (5) is equivalent to the corporate tax expression in Modigliani and Miller (1963, p. 439). If in addition to corporate taxes, personal taxes also exist, while debt is still risk free, then $\mathrm{q}=0$ and $\Psi$ simply reduces to (1-T), and, consequently, Equation (2) reduces to the following:

$$
K_{E}=K_{U}+T\left[K_{U}-r\left(1-T_{D}\right)\right] L .
$$

In theory, as the tax rate on interest income increases relative to the tax rate on equity income, bondholders demand relatively higher pretax returns to leave them equally well off on an after-tax basis. The resulting higher interest cost reduces the tax benefit from debt accruing to equity holders. As a result, the equity risk premium from leverage should increase with the personal tax penalty on interest income according to Miller (1977).

Next, we turn to the derivation of the variance (or standard deviation) for each of the K expressions above. The $\sigma \mathrm{E}-\mathrm{L}$ expressions corresponding to Equations (3), (5), and (6) are as follows:

$$
\begin{gathered}
\sigma_{E}=\sigma_{U}+\sigma_{U} \mathrm{~L}, \\
\sigma_{E}=\sigma_{U}+\sigma_{U}\left(1-T_{C}\right) \mathrm{L}, \\
\sigma_{E}=\sigma_{U}+\sigma_{U}(T L) .
\end{gathered}
$$

1 The general variance expression corresponding to the general K expression given by Equation (2), which incorporates both corporate and personal taxes as well as risky debt and bankruptcy costs is Equation (2a):

$$
\sigma_{E}^{2}=\sigma_{U}^{2}[1+(1-\Psi) L]^{2}+\sigma^{2} D\left(1-T_{C}\right)^{2}\left(1-T_{E}\right)^{2} L^{2}-2 \operatorname{cov}\left(K_{U}, r\right)
$$


Next, we explain the methodology of testing the $\sigma \mathrm{E}-\mathrm{L}$ theoretical models. We divide our tests into two main stages. In the first stage, we test the direct relationship between $\sigma_{\mathrm{E}}$ and $\mathrm{L}$ using an ordinary least squares (OLS) regression analysis for the following three cases: No taxes, corporate taxes only, and both corporate and personal taxes. The second stage of our test will present comparative tests whose purpose is to determine which of the above three cases better corresponds to the real world relationship. We use two methods of testing: Method 1 and method 2. Method 1 involves the comparison of the observed $\gamma_{0}, \gamma_{1}$ (from each direct regression) with their theoretical counterparts, $\gamma_{0}{ }^{*}, \gamma_{1}^{*}$.

The alternative test method (method 2 ) involves two stages. The first stage is the following regression estimation of Equation (7):

$$
\sigma_{\mathrm{E}}=\gamma_{0}+\gamma_{1}[\mathrm{~L}]
$$

Using this estimation procedure, $\gamma_{1}$ should account for the effect of all market imperfections. Thus, in the second stage, we compare $\gamma_{0}$ with $\sigma_{\mathrm{U}}$, where $\sigma_{\mathrm{U}}$ is derived from the corresponding model, and we compare $\gamma_{1}$ with the theoretical slope in the corresponding theoretical model. For example, for model (3a), where corporate and personal taxes are the only market imperfections, $\gamma_{0}$ should be equal to $\sigma_{U}$, where $\sigma_{U}=\sigma_{E} /(1+\mathrm{TL})$, and $\gamma_{1}$ should be equal to $\sigma_{U} \mathrm{~T}$. Note that in all three cases (a perfect capital market, corporate taxes, and corporate and personal taxes), we should expect a positive slope, representing the positive relationship between $\sigma_{\mathrm{E}}$ and $\mathrm{L}$.

\section{Data and Variable Measurement}

\subsection{Data}

We gathered the financial and market data from two main sources: The COMPUSTAT database and the Yahoo stock screener. Testing the various theoretical models outlined above requires a reference to the risk class issue. Theory states that the $\sigma_{U}$ should be identical across all firms in the same risk class. Consequently, an empirical problem that can arise is that $\sigma_{U}$ is supposed to be constant in the defined risk class, but, practically, it may vary across the companies in the same risk class. Taken to the extreme, $\sigma_{U}$ may practically even vary from one company to another. The empirical tradeoff involved then is between selecting a very small sample in order to maintain a homogenous risk class on the one hand, and the low statistical reliability that may be associated with a relatively small sample. Given this tradeoff, we selected our sample to consist of the industrial sector according to the GICS (Global Industry Classification Standards) definition of COMPUSTAT and, at the same time, is sufficiently large to obtain statistically reliable results. Furthermore, to reduce the "survival bias" discussed in the literature, our sample in the various years contains precisely the same set of companies (which naturally reduced the size of our initial sample). In addition, to minimize the potential measurement errors caused, among other things, by our relatively broad risk class assumption, we employed various sensitivity analyses and robustness tests discussed later in this study. Our sample time period ended at 2007 since the Haifa university subscription to COMPUSTAT expired at the end of 2007. Also, to focus on the most recent normal years available, the starting point year was defined here as 2003, since prior years to 2003 were associated with the rise and burst of the so called high tech bubble. The initial sample consisted of all 306 firms and companies covered by COMPUSTAT in the sample time period. We then required complete data in each sample year on the company's total debt, current liabilities, total equity, total taxes paid, pretax income, total dividend paid, and preferred stocks in each year and also the historical 60 monthly returns. This screening procedure reduced our sample to 182 firms. Since no data was available for estimating the " $\operatorname{cov}\left(\mathrm{K}_{\mathrm{U}}, \mathrm{r}\right)$ " term, our empirical analysis will be based on the debt risk free models described in the previous section. This is also consistent with the empirical approach adopted by many prior empirical studies, which only employed models in which debt is assumed to be risk free. 


\subsection{Variable Measurement}

The variables in our study include the financial leverage $(\mathrm{L})$, the standard deviation of stock returns $\left(\sigma_{E}\right)$, and the tax rates-corporate and personal $\left(T_{C}, T_{D}\right.$, and $\left.T_{E}\right)$. We gathered all of the required data from the balance sheets and income statements of each firm in each sample year and market data, such as stock prices and returns.

To test for the robustness of our results and overcome the potential problem of measurement errors, we used several estimates of the financial leverage and tax variables combined with different methods of estimating them.

\subsubsection{Financial Leverage}

The literature is replete with financial leverage measures that include both market and book measures for equity and debt. Barclay et al. (2006) show how book leverage is theoretically preferred in regressions involving financial leverage. Using book values may be justified by a survey of Graham and Harvey (2001), who reports that managers focus on book values when considering the financial structure of the firm. Welch (2004) argues against book values, and Fama and French (2002) find different results for book and market leverage. On the other hand, Bowman (1980) has used various estimates of the financial leverage in terms of both book and market values, and concluded that the estimates are not statistically different from each other in terms of the relationship between risk and leverage. Thus, the literature is not unanimous about the optimal way of assessing the appropriate financial leverage measure. Appendix A provide a review of various proxies for financial leverage in the empirical literature.

Since financial leverage is a central variable in this study, we used two L measures based on the long-term debt of the firm: Lev $_{1}=$ LTD/Equity ${ }_{B V}$ and Lev $_{2}=$ LTD/EquityMV. We also used two other L measures to include current liabilities: $\mathrm{Lev}_{3}=(\mathrm{LTD}+\mathrm{CL}) /$ Equity $\mathrm{BV}_{\mathrm{B}}$ and $\mathrm{Lev}_{4}=(\mathrm{LTD}+\mathrm{CL}) / \mathrm{Equity}_{\mathrm{MV}}$. Lev denotes the financial leverage, LTD is long-term debt, Equity is the value of common equity, CL is the current liabilities, and the subscripts, BV and MV, stand for the book and market values, respectively. Equity ${ }_{M V}$ includes the market value of common equity given by the product of the number of common shares outstanding and the mean of the 12 monthly closing stock prices. The estimate of the financial leverage (Lev) for each year is based on the mean value of the preceding five years. We constructed two such estimates-Relative and Absolute. The Relative Lev estimate for a given year is the mean value of the Lev variable across the preceding five years, while the Absolute Lev is given by the 5-year mean value of the "debt" numerator divided by the 5-year mean value of the "equity" denominator. Following previous relevant empirical works, we used the book value of debt. Additional estimates include using preferred equity in the "debt" component. The preferred stock estimates are not presented here, because the results with and without preferred stock remained similar. To summarize, eight different versions of the financial leverage variable are considered here-four using the Absolute method and four using the Relative method of leverage calculation. Each one of the eight leverages (both book and market measures) will be used to test the theoretical models. Accordingly, each one of them will be employed in the unlevering formulas.

\subsubsection{Corporate and Personal Taxes}

Testing Equations (7)-(9) requires estimates of the corporate tax rate $\left(T_{C}\right)$ and the personal tax rates applicable to the equity holders $\left(\mathrm{T}_{\mathrm{E}}\right)$ and the debt holders $\left(\mathrm{T}_{\mathrm{D}}\right)$. Most proxies for the corporate tax rate are based on the total income tax expense divided by the pre-tax income (Fan et al. (2012); Arena and Roper (2010); Dyreng et al. (2010); Butler et al. (1991)), or by assuming a constant corporate tax rate (DeAngelo et al. (2011); Kemsley and Nissim (2002); Marston and Perry (1996)). Following the first set of studies, we used the total tax expense divided by the pretax income as a proxy for the corporate tax variable. The estimate of the corporate tax rate $\left(T_{C}\right)$ for each year is based on the mean value of the preceding five years. Again, we constructed two such estimates-Relative and Absolute. 
The Relative $T_{C}$ estimate for a given year is the mean value of the $T_{C}$ variable across the preceding five years, while the Absolute $T_{C}$ is given by the 5-year mean value of the firm's total tax expense divided by the 5 -year mean value of the firm's taxable income. Butler et al. (1991) set the outliers of corporate tax rates to $40 \%$, because such rates are likely to be associated with non-recurring or unusual items. They state that this procedure is necessary for approximately $15 \%$ of the sample firms. We follow that procedure here for approximately $12 \%$ of the sample. We set the corporate tax rates that exceed $60 \%$ to the mean value plus two standard deviations, and the corporate tax rates that are less than $20 \%$ to the mean value minus two standard deviations.

The personal tax rate is a function of the tax rates faced by debt holders $\left(T_{D}\right)$, and the tax rate faced by equity holders $\left(T_{E}\right)$. Two factors determine the latter: The tax rates on dividend $\left(T_{d}\right)$ and capital gains $\left(T_{c g}\right)$ income. Following Dhaliwal et al. (2006) (henceforth: DHL), we set $T_{D}$ to the highest statutory tax rate on interest income. We also estimated $T_{E}$ according to DHL's modification of the tax rate on equity income to represent a weighted-average tax rate on dividend and capital gains income by the following term: $\left[d \cdot T_{d}+(1-\mathrm{d}) \cdot \alpha \cdot T_{c g}\right]$, where $d$ is the amount per after-corporate tax dollar of earnings that is distributed to shareholders in the form of a dividend. $d$ represents the dividends paid for the most recent year divided by the average earnings over the prior three years, and accordingly, $(1-\mathrm{d})$ is the retention rate.

Following the procedure used by Dhaliwal et al. (2006), we winsorize $d$ at zero and one. $T_{d}$ is the personal tax rate on dividend income, set to equal $T_{D}$ for the years prior to 2003 , and $15 \%$ thereafter. $T_{c g}$ is set to equal the top statutory tax rate on long-term capital gains income, which equals $20 \%$ for 1998 through to 2002 and $15 \%$ thereafter. $\alpha$ is the benefit of capital gains deferral. This benefit stems from the lower present value of future tax payments, especially if the capital gains are realized in future time periods when the investor's personal tax rate is lower than the corresponding tax rate in the present. A very informal rule is to multiply the statutory capital gains tax rate by 0.25 to capture the fact that the present value of the expected capital gains taxes is small ${ }^{2}$.

Following Van Binsbergen et al. (2010); Graham (1999); Dhaliwal et al. (2006), we assumed that $\alpha=0.25$. To summarize, the personal tax rate is a function of $T_{D}, T_{d}, T_{c g}$, and $d$, and equal to $\left(1-T_{E}\right) /\left(1-T_{D}\right)$.

\section{Empirical Findings}

\subsection{Descriptive Statistics}

Table 1 reports the descriptive statistics for our sample. The values reported are measured in \$millions and include the mean, median (Med), standard deviation (SD), coefficient of variation (CV), minimum (Min), and maximum (Max). For example, the mean value of the total liabilities of the firms is $\$ 6720.1$ million, and the mean value of their common equity is $\$ 2269.7$ million. The standard deviations of these corresponding variables are $\$ 533.9$ and $\$ 312.7$ million, which reflect a coefficient of variation $(\mathrm{CV})$ of 0.08 and 0.14 , respectively.

Table 1 also reports our measurements for the financial leverage according to eight measures of $\mathrm{L}$ according to the Relative and Absolute computation methods.

The Lev 1 rows in Table 1 present the descriptive statistics of the ratio of long-term debt to (book) equity, and the $\operatorname{Lev}_{2}$ rows report the descriptive statistics when the market value of equity is used. Similarly, the $\mathrm{Lev}_{3}$ rows present the descriptive results of the ratio of total debt to total (book) equity, and the $\mathrm{Lev}_{4}$ rows report these results when the market value of equity is used. For example, the mean value of long-term debt to total book equity by the relative computation method (Relative $\operatorname{Lev}_{1}$ ) is 0.84 and 0.51 by $\operatorname{Lev}_{2}$. Similarly, the mean value of $\operatorname{Lev}_{3}$ is 1.65 and 1.02 for $\operatorname{Lev}_{4}$. It is clear that market,

2 We would like to thank John Graham for clarifying this point to us. 
rather than book measures, tend to generate lower L values, because the market value of equity is generally higher than the book value of equity.

Table 1 also reports the descriptive statistics for the measurement of the dependent variable $\left(\sigma_{\mathrm{E}}\right)$. $\sigma_{\mathrm{E}}$ is the historical standard deviation (HSD) for each firm based on the monthly stock returns in five years prior to each sample year. The mean (median) value of $\sigma_{\mathrm{E}}$ across the years is $0.114(0.096)$ and the min-max range is $0.048-0.421$. Additional descriptive statistics for other key variables, such as corporate $\left(\mathrm{T}_{\mathrm{C}}\right)$ and personal taxes $\left(\mathrm{T}_{\mathrm{E}}\right.$ and $\left.\mathrm{T}_{\mathrm{R}}\right)$, are also included in Table 1. For example, the mean value of the corporate tax rate by the Absolute-computation method (Absolute $\mathrm{T}_{\mathrm{C}}$ ) is 0.348 , while by the Relative-computation method (Relative $\mathrm{T}_{\mathrm{C}}$ ) measure the corresponding mean value is 0.358 by the absolute corporate tax measure. Overall, the estimation of the corporate tax rate by either the Absolute or the relative computation methods yields similar $\mathrm{T}_{\mathrm{C}}$ measures for each of the sample years, and therefore we report here only the mean value across the years.

Table 1. Descriptive statistics of the corporate variables $(\$ M)$.

\begin{tabular}{|c|c|c|c|c|c|c|}
\hline & Mean & Med & SD & $\mathrm{CV}$ & Min & Max \\
\hline Total Liabilities & 6720.10 & 6705.60 & 533.9 & 0.08 & 6098.40 & 7556.30 \\
\hline Common Equity & 2269.70 & 2280.80 & 312.7 & 0.14 & 1833.50 & 2693.20 \\
\hline Total Assets & 8989.70 & 8872.40 & 834.6 & 0.09 & 7931.90 & $10,249.50$ \\
\hline Current Liabilities & 2931.60 & 2929.50 & 219.1 & 0.07 & 2657.20 & 3206.80 \\
\hline Long-Term Debt & 2429.90 & 2272.40 & 365.8 & 0.15 & 2053.50 & 2998.80 \\
\hline Deferred Taxes & 308.2 & 311.3 & 35.6 & 0.12 & 251.9 & 345.8 \\
\hline Pref. Equity & 1.8 & 1.5 & 0.9 & 0.5 & 0.7 & 3 \\
\hline Common Shares & 173.5 & 174.1 & 2.2 & 0.01 & 170.5 & 175.6 \\
\hline Pretax Income & 517.2 & 501.6 & 148.3 & 0.29 & 341 & 709.4 \\
\hline Tax Expense & 140.6 & 134.4 & 42.2 & 0.3 & 95.4 & 198 \\
\hline Relative Lev1 & 0.84 & 0.81 & 0.06 & 0.07 & 0.77 & 0.92 \\
\hline Relative Lev2 & 0.51 & 0.51 & 0.08 & 0.16 & 0.4 & 0.59 \\
\hline Relative Lev3 & 1.65 & 1.61 & 0.09 & 0.05 & 1.56 & 1.78 \\
\hline Relative Lev4 & 1.02 & 1.03 & 0.15 & 0.15 & 0.82 & 1.19 \\
\hline Absolute Lev1 & 0.8 & 0.81 & 0.04 & 0.05 & 0.76 & 0.84 \\
\hline Absolute Lev2 & 0.38 & 0.34 & 0.15 & 0.4 & 0.23 & 0.61 \\
\hline Absolute Lev3 & 1.55 & 1.55 & 0.07 & 0.05 & 1.45 & 1.64 \\
\hline Absolute Lev4 & 0.74 & 0.69 & 0.26 & 0.35 & 0.49 & 1.14 \\
\hline$\sigma_{\mathrm{E}}$ & 0.114 & 0.096 & 0.057 & 0.499 & 0.048 & 0.421 \\
\hline Absolute $\mathrm{T}_{\mathrm{C}}$ & 0.348 & 0.347 & 0.067 & 0.193 & 0.209 & 0.519 \\
\hline Relative $\mathrm{T}_{\mathrm{C}}$ & 0.358 & 0.354 & 0.078 & 0.219 & 0.205 & 0.572 \\
\hline D & 0.205 & 0.17 & 0.222 & 1.078 & 0 & 1 \\
\hline $\mathrm{T}_{\mathrm{E}}$ & 0.061 & 0.057 & 0.025 & 0.411 & 0.038 & 0.15 \\
\hline $\mathrm{T}_{\mathrm{R}}$ & 1.445 & 1.451 & 0.038 & 0.027 & 1.308 & 1.481 \\
\hline
\end{tabular}

Notes: Table 1 reports the descriptive sample statistics. All financial statement data are gathered from the COMPUSTAT database. The values reported are measured in \$millions except for common shares outstanding. The reported statistics are the mean, median (med), standard deviation (SD), coefficient of variation (CV), minimum (min), and maximum (max). Lev1 is the ratio of LTD/Equity ${ }_{B V}$, Lev2 is the ratio of LTD/Equity ratio of (LTD + CL/EquityBV), and Lev4 is the ratio of (LTD + CL/EquityMv), where Lev denotes the financial leverage, LTD is long-term debt in book value, equity is the total value of common equity, CL is the current liabilities, and the subscripts, BV and MV, stand for book and market values, respectively. The estimate of the financial leverage for each year is based on the mean value over the preceding five years. Two such estimates have been constructed-Relative and Absolute. The relative Lev estimate for a given year is the mean value of the Lev variable across the preceding five years, while the Absolute Lev is given as the 5-year mean value of the "debt" numerator divided by the 5-year mean value of the "equity" denominator. $\sigma_{\mathrm{E}}$ is the historical standard deviation (HSD) of stock returns based on 60 monthly observations. The Relative $\mathrm{T}_{\mathrm{C}}$ estimate for a given year is the mean value of the $T_{C}$ variable across the preceding five years, while the Absolute $T_{C}$ is given by the 5 -year mean value of the firm's total tax expense divided by the 5-year mean value of the firm's taxable income. The table also reports the payout ratio $(d)$, the personal tax rate $\left(T_{E}\right)$, and the taxes ratio $\left[\left(T_{R}\right) ; T_{R}=\left(1-T_{E}\right) /\left(1-T_{D}\right)\right] . T_{E}$ is the tax rate applicable to equity holders, and $\mathrm{T}_{\mathrm{D}}$ is the tax rate applicable to debt holders. $\mathrm{T}_{\mathrm{D}}$ is the highest statutory tax rate on interest income, which is $39.6 \%$ for 1998 through to $2000,38.6 \%$ for 2001 through to 2002 , and 35\% thereafter. We estimate $\mathrm{T}_{\mathrm{E}}$ as a weighted-average tax rate on dividend and capital gains income using the following term: $T_{E}=\left[d \cdot T_{d}+(1-d) \cdot \alpha \cdot T_{c g}\right]$, where $d$ is the proportion of the net income distribution paid out in dividends, and $(1-\mathrm{d})$ is the retention ratio. Following the procedure devised by Dhaliwal et al. (2006), we winsorized at zero and one. $T_{d}$ is the personal tax rate on dividend income, set to equal the values of $T_{D}$ for the years prior to 2003, and $15 \%$ thereafter. $\mathrm{T}_{\mathrm{cg}}$ is set to equal the top statutory tax rate on long-term capital gains income, which equals $20 \%$ for 1998 through to 2002 and 15\% thereafter. $\alpha$ is the benefit of capital gains deferral. Following Graham (1999) and Dhaliwal et al. (2006), we assume that $\alpha=0.25$. The sample size (N) relevant to this table as well as to the subsequent tables is 182 companies. 


\subsection{Regression Results}

Table 2 presents the findings for the tested models with respect to the following cases: Perfect capital markets, corporate taxes, and both corporate and personal taxes. The results are reported for two different L measures $\left[\operatorname{Lev}_{4}(\mathrm{Mv})\right.$ and $\left.\mathrm{Lev}_{3}(\mathrm{Bv})\right]$, which are based on the total debt of the firm. Using other L measures yields similar results. The statistics reported for each regression are the intercept, slope, R-squared, and the significance of the slope OLS coefficient by the null hypothesis HO: $\gamma_{1}=0$ vs. H1: $\gamma_{1} \neq 0$. Since the intercept was significant at the $1 \%$ level in all cases, only the significance of the slope is reported in the tables. Additional tests comparing whether each regression parameter is equal to its theoretical counterpart in each sample year are provided in Tables 3 and 4.

Table 2. Regression results.

\begin{tabular}{|c|c|c|c|c|c|c|c|}
\hline \multicolumn{2}{|c|}{ Perfect Capital Market } & Mean & Median & SD & $\mathrm{CV}$ & Min & $\operatorname{Max}$ \\
\hline \multirow{3}{*}{$\mathrm{Lev}_{4}(\mathrm{Mv}) \mathrm{Rel}$} & Intercept & 0.092 & 0.093 & 0.013 & 0.140 & 0.077 & 0.108 \\
\hline & Slope & 0.021 & 0.022 & 0.001 & 0.062 & 0.019 & 0.022 \\
\hline & $\mathrm{R}^{2}$ & 0.189 & 0.175 & 0.030 & 0.159 & 0.166 & 0.241 \\
\hline $\mathrm{HO}: \gamma_{1}=0$ & Slope Sig & 0.000 & 0.000 & 0.000 & 0.000 & 0.000 & 0.000 \\
\hline \multirow{3}{*}{$\mathrm{Lev}_{3}(\mathrm{Bv}) \mathrm{Rel}$} & Intercept & 0.095 & 0.094 & 0.015 & 0.157 & 0.080 & 0.116 \\
\hline & Slope & 0.011 & 0.012 & 0.002 & 0.182 & 0.008 & 0.013 \\
\hline & $\mathrm{R}^{2}$ & 0.110 & 0.110 & 0.030 & 0.277 & 0.077 & 0.159 \\
\hline $\mathrm{HO}: \gamma_{1}=0$ & Slope Sig & 0.000 & 0.000 & 0.000 & 0.000 & 0.000 & 0.000 \\
\hline \multicolumn{2}{|c|}{ Corporate Taxes } & Mean & Median & SD & $\mathrm{CV}$ & Min & $\operatorname{Max}$ \\
\hline \multirow{3}{*}{$\mathrm{Lev}_{4}(\mathrm{Mv}) \mathrm{Rel}$} & Intercept & 0.093 & 0.092 & 0.013 & 0.143 & 0.078 & 0.110 \\
\hline & Slope & 0.032 & 0.032 & 0.003 & 0.093 & 0.027 & 0.035 \\
\hline & $\mathrm{R}^{2}$ & 0.184 & 0.175 & 0.037 & 0.200 & 0.149 & 0.246 \\
\hline$\gamma_{1}=0$ & Slope Sig & 0.000 & 0.000 & 0.000 & 0.000 & 0.000 & 0.000 \\
\hline \multirow{3}{*}{$\mathrm{Lev}_{3}(\mathrm{Bv}) \mathrm{Rel}$} & Intercept & 0.097 & 0.094 & 0.016 & 0.170 & 0.080 & 0.119 \\
\hline & Slope & 0.016 & 0.017 & 0.003 & 0.207 & 0.012 & 0.020 \\
\hline & $\mathrm{R}^{\frac{1}{2}}$ & 0.103 & 0.099 & 0.040 & 0.384 & 0.055 & 0.165 \\
\hline HO: $\gamma_{1}=0$ & Slope Sig & 0.000 & 0.000 & 0.000 & 0.000 & 0.000 & 0.001 \\
\hline \multicolumn{2}{|c|}{ Corporate + Personal Taxes } & Mean & Median & SD & $\mathrm{CV}$ & Min & Max \\
\hline \multirow{3}{*}{$\mathrm{Lev}_{4}(\mathrm{Mv})$ Rel } & Intercept & 0.093 & 0.092 & 0.013 & 0.143 & 0.078 & 0.110 \\
\hline & Slope & 0.022 & 0.022 & 0.002 & 0.105 & 0.018 & 0.024 \\
\hline & $\mathrm{R}^{2}$ & 0.190 & 0.181 & 0.037 & 0.194 & 0.154 & 0.252 \\
\hline HO: $\gamma_{1}=0$ & Slope Sig & 0.000 & 0.000 & 0.000 & 0.000 & 0.000 & 0.000 \\
\hline \multirow{3}{*}{$\mathrm{Lev}_{3}(\mathrm{Bv}) \mathrm{Rel}$} & Intercept & 0.096 & 0.093 & 0.017 & 0.175 & 0.079 & 0.119 \\
\hline & Slope & 0.011 & 0.012 & 0.002 & 0.223 & 0.008 & 0.014 \\
\hline & $R^{\frac{1}{2}}$ & 0.111 & 0.107 & 0.041 & 0.367 & 0.061 & 0.174 \\
\hline HO: $\gamma_{1}=0$ & Slope Sig & 0.000 & 0.000 & 0.000 & 0.000 & 0.000 & 0.001 \\
\hline
\end{tabular}

Notes: Table 2 presents the regression results of: Model (1a): $\sigma_{E}=\sigma_{U}+\sigma_{U}[\mathrm{~L}]$ using the estimated regression equation given by: $\sigma_{\mathrm{E}}=\gamma_{0}+\gamma_{1}[\mathrm{~L}]$, $\operatorname{Model}(2 \mathrm{a}): \sigma_{\mathrm{E}}=\sigma_{\mathrm{U}}+\sigma_{\mathrm{U}}\left[\left(1-\mathrm{T}_{\mathrm{C}}\right) \mathrm{L}\right]$ using the estimated regression equation given by: $\sigma_{E}=\gamma_{0}+\gamma_{1}\left[\left(1-\mathrm{T}_{\mathrm{C}}\right) \mathrm{L}\right]$, Model $(3 \mathrm{a}): \sigma_{\mathrm{E}}=\sigma_{\mathrm{U}}+\sigma_{\mathrm{U}}[\mathrm{TL}]$ using the estimated regression equation given by: $\sigma_{\mathrm{E}}=\gamma_{0}+\gamma_{1}[\mathrm{TL}] . \sigma_{\mathrm{E}}$ is the risk coefficient of the equity in terms of standard deviation; L is the financial leverage $\left(\mathrm{Lev}_{3}, \mathrm{Lev}_{4}\right)$ of the firm using the Relative estimate (Rel) for a given year, which is the mean value of the Lev variable across the preceding five years, while the Absolute (Abs) is given by the 5-year mean value of the "debt" numerator divided by the 5-year mean value of the "equity" denominator. Lev $=(C L+L T D) / E q u i t y B V$, $\mathrm{Lev}_{4}=(\mathrm{CL}+\mathrm{LTD}) /$ Equity $_{\mathrm{MV}}$ where Lev denotes the financial leverage, LTD is long-term debt, CL is the current liabilities, Equity is the value of common equity, and the subscripts, BV and MV, stand for book and market values, respectively. Slope sig refers to the usual null hypothesis: H0: $\gamma_{1}=0$ vs. H1: $\gamma_{1} \neq 0$. The sample size (N) is 182 companies. 
Table 3. Comparison results by method 1 .

\begin{tabular}{|c|c|c|c|c|c|c|c|c|c|c|c|c|c|c|c|c|}
\hline \multicolumn{2}{|c|}{ Panel A } & \multicolumn{3}{|c|}{2007} & \multicolumn{3}{|c|}{2006} & \multicolumn{3}{|c|}{2005} & \multicolumn{3}{|c|}{2004} & \multicolumn{3}{|c|}{2003} \\
\hline \multicolumn{17}{|c|}{ Risk Free Debt Models } \\
\hline \multicolumn{2}{|c|}{$\operatorname{Lev}_{4}(\mathrm{Mv}) \mathrm{Rel}$} & $\sigma_{U^{*}}^{*}$ & $\gamma_{0}$ & $\gamma_{1}$ & $\sigma_{U^{*}}$ & $\gamma_{0}$ & $\gamma_{1}$ & $\sigma_{U^{*}}^{*}$ & $\gamma_{0}$ & $\gamma_{1}$ & $\sigma_{U^{*}}^{*}$ & $\gamma_{0}$ & $\gamma_{1}$ & $\sigma_{U^{*}}^{*}$ & $\gamma_{0}$ & $\gamma_{1}$ \\
\hline & $1 \mathrm{a}$ & 0.051 & 0.077 & 0.019 & 0.053 & 0.082 & 0.021 & 0.057 & 0.093 & 0.022 & 0.059 & 0.101 & 0.022 & 0.061 & 0.108 & 0.022 \\
\hline $\operatorname{Rel} \mathrm{T}_{\mathrm{C}}$ & $2 a$ & 0.060 & 0.077 & 0.028 & 0.063 & 0.082 & 0.033 & 0.069 & 0.093 & 0.033 & 0.073 & 0.100 & 0.036 & 0.077 & 0.108 & 0.035 \\
\hline Abs $\mathrm{T}_{\mathrm{C}}$ & $2 a$ & 0.060 & 0.078 & 0.027 & 0.063 & 0.082 & 0.032 & 0.069 & 0.092 & 0.035 & 0.072 & 0.101 & 0.033 & 0.076 & 0.110 & 0.032 \\
\hline $\operatorname{Rel} \mathrm{T}_{\mathrm{C}}$ & $3 a$ & 0.052 & 0.077 & 0.019 & 0.054 & 0.081 & 0.023 & 0.059 & 0.093 & 0.023 & 0.062 & 0.099 & 0.025 & 0.065 & 0.108 & 0.024 \\
\hline$A b s \mathrm{~T}_{\mathrm{C}}$ & $3 a$ & 0.052 & 0.078 & 0.018 & 0.054 & 0.082 & 0.022 & 0.058 & 0.092 & 0.024 & 0.061 & 0.101 & 0.023 & 0.064 & 0.110 & 0.022 \\
\hline \multicolumn{2}{|c|}{ Mean } & 0.055 & 0.077 & 0.022 & 0.057 & 0.082 & 0.026 & 0.062 & 0.093 & 0.027 & 0.065 & 0.100 & 0.028 & 0.069 & 0.109 & 0.027 \\
\hline \multicolumn{2}{|c|}{ Median } & 0.052 & 0.077 & 0.019 & 0.054 & 0.082 & 0.023 & 0.059 & 0.093 & 0.024 & 0.062 & 0.101 & 0.025 & 0.065 & 0.108 & 0.024 \\
\hline \multicolumn{2}{|c|}{ SD } & 0.005 & 0.001 & 0.005 & 0.005 & 0.000 & 0.006 & 0.006 & 0.001 & 0.006 & 0.007 & 0.001 & 0.006 & 0.007 & 0.001 & 0.006 \\
\hline \multicolumn{2}{|l|}{ Min } & 0.051 & 0.077 & 0.018 & 0.053 & 0.081 & 0.021 & 0.057 & 0.092 & 0.022 & 0.059 & 0.099 & 0.022 & 0.061 & 0.108 & 0.022 \\
\hline \multicolumn{2}{|l|}{$\operatorname{Max}$} & 0.06 & 0.078 & 0.028 & 0.063 & 0.082 & 0.033 & 0.069 & 0.093 & 0.035 & 0.073 & 0.101 & 0.036 & 0.077 & 0.11 & 0.035 \\
\hline \multicolumn{2}{|c|}{$\operatorname{Lev}_{3}(\mathrm{Bv}) \mathrm{Rel}$} & $\sigma_{U^{*}}^{*}$ & $\gamma_{0}$ & $\gamma_{1}$ & $\sigma_{U^{*}}$ & $\gamma_{0}$ & $\gamma_{1}$ & $\sigma_{U^{*}}{ }^{*}$ & $\gamma_{0}$ & $\gamma_{1}$ & $\sigma_{U^{*}}^{*}$ & $\gamma_{0}$ & $\gamma_{1}$ & $\sigma_{U^{*}}$ & $\gamma_{0}$ & $\gamma_{1}$ \\
\hline & $1 a$ & 0.036 & 0.081 & 0.008 & 0.039 & 0.083 & 0.012 & 0.044 & 0.094 & 0.013 & 0.046 & 0.104 & 0.012 & 0.048 & 0.116 & 0.010 \\
\hline $\operatorname{Rel} \mathrm{T}_{\mathrm{C}}$ & $2 a$ & 0.046 & 0.081 & 0.011 & 0.050 & 0.085 & 0.015 & 0.057 & 0.096 & 0.019 & 0.060 & 0.106 & 0.017 & 0.063 & 0.118 & 0.014 \\
\hline$A b s \mathrm{~T}_{\mathrm{C}}$ & $2 a$ & 0.046 & 0.080 & 0.012 & 0.049 & 0.083 & 0.017 & 0.056 & 0.094 & 0.020 & 0.059 & 0.107 & 0.017 & 0.063 & 0.119 & 0.013 \\
\hline $\operatorname{Rel} \mathrm{T}_{\mathrm{C}}$ & $3 a$ & 0.037 & 0.080 & 0.008 & 0.040 & 0.085 & 0.010 & 0.046 & 0.095 & 0.014 & 0.049 & 0.106 & 0.012 & 0.051 & 0.118 & 0.010 \\
\hline$A b s \mathrm{~T}_{\mathrm{C}}$ & $3 a$ & 0.053 & 0.079 & 0.008 & 0.057 & 0.082 & 0.012 & 0.065 & 0.093 & 0.014 & 0.069 & 0.106 & 0.012 & 0.073 & 0.119 & 0.009 \\
\hline \multicolumn{2}{|c|}{ Mean } & 0.044 & 0.080 & 0.009 & 0.047 & 0.084 & 0.013 & 0.054 & 0.094 & 0.016 & 0.057 & 0.106 & 0.014 & 0.060 & 0.118 & 0.011 \\
\hline \multicolumn{2}{|c|}{ Median } & 0.046 & 0.08 & 0.008 & 0.049 & 0.083 & 0.012 & 0.056 & 0.094 & 0.014 & 0.059 & 0.106 & 0.012 & 0.063 & 0.118 & 0.01 \\
\hline \multicolumn{2}{|l|}{ SD } & 0.007 & 0.001 & 0.002 & 0.008 & 0.001 & 0.003 & 0.009 & 0.001 & 0.003 & 0.009 & 0.001 & 0.003 & 0.010 & 0.001 & 0.002 \\
\hline \multicolumn{2}{|l|}{ Min } & 0.036 & 0.079 & 0.008 & 0.039 & 0.082 & 0.01 & 0.044 & 0.093 & 0.013 & 0.046 & 0.104 & 0.012 & 0.048 & 0.116 & 0.009 \\
\hline \multicolumn{2}{|c|}{ Max } & 0.053 & 0.081 & 0.012 & 0.057 & 0.085 & 0.017 & 0.065 & 0.096 & 0.02 & 0.069 & 0.107 & 0.017 & 0.073 & 0.119 & 0.014 \\
\hline \multicolumn{2}{|c|}{ Panel B } & \multicolumn{3}{|c|}{2007} & \multicolumn{3}{|c|}{2006} & \multicolumn{3}{|c|}{2005} & & 2004 & & & 2003 & \\
\hline $\operatorname{Lev}_{4}(\mathrm{Mv}$ & Rel & $\gamma_{0}-\sigma_{\mathrm{U}}^{*}$ & $\gamma_{1}$ & $\sigma_{U^{*}}$ & $\gamma_{0}-\sigma_{U^{*}}^{*}$ & $\gamma_{1}$ & $\sigma_{U^{*}}$ & $\gamma_{0}-\sigma_{\mathrm{U}}^{*}$ & $\gamma_{1}$ & & $\gamma_{0}-\sigma_{\mathrm{U}}^{*}$ & $\gamma_{1}$ & & $\gamma_{0}-\sigma_{\mathrm{U}}^{*}$ & $\gamma_{1}$ & $\sigma_{U^{*}}$ \\
\hline & $1 \mathrm{a}$ & $0.026^{*}$ & -0 . & & $0.029^{*}$ & -0 & $32 *$ & $0.036^{*}$ & & & $0.042 *$ & -0 & & $0.047^{*}$ & & \\
\hline $\operatorname{Rel} \mathrm{T}_{\mathrm{C}}$ & $2 a$ & 0.017 * & -0 & $32 *$ & 0.019 * & -0 & $30 *$ & 0.024 * & & & $0.027^{*}$ & -0 & & $0.031 *$ & & \\
\hline$A b s \mathrm{~T}_{\mathrm{C}}$ & $2 a$ & $0.018 *$ & -0 . & $33 *$ & $0.019 *$ & -0 & $31 *$ & $0.023 *$ & -0 & & 0.029 & -0 & & $0.034 *$ & & $44 *$ \\
\hline $\operatorname{Rel} \mathrm{T}_{\mathrm{C}}$ & $3 a$ & 0.025 * & -0 . & $33 *$ & $0.027^{*}$ & -0 & $31 *$ & $0.034 *$ & -0 & & 0.037 * & -0 & & 0.043 * & -0 & 41 * \\
\hline$A b s \mathrm{~T}_{\mathrm{C}}$ & $3 a$ & $0.026^{*}$ & -0 . & $34 *$ & $0.028^{*}$ & -0 & $32 *$ & $0.034^{*}$ & -0 & & $0.040 *$ & -0 . & & $0.046^{*}$ & & $42 *$ \\
\hline Mear & & 0.022 & & & 0.024 & & & 0.030 & & & 0.035 & & & 0.040 & & \\
\hline Media & & 0.025 & & & 0.027 & & & 0.034 & & & 0.037 & & & 0.043 & & \\
\hline SD & & 0.005 & & & 0.005 & & & 0.006 & & & 0.007 & & & 0.007 & & \\
\hline Min & & 0.017 & & & 0.019 & & & 0.023 & & & 0.027 & & & 0.031 & & \\
\hline Max & & 0.026 & -0 & & 0.029 & & & 0.036 & & & 0.042 & & & 0.047 & & \\
\hline
\end{tabular}


Table 3. Cont.

\begin{tabular}{|c|c|c|c|c|c|c|c|c|c|c|c|}
\hline \multirow{2}{*}{\multicolumn{2}{|c|}{$\begin{array}{c}\text { Panel B } \\
\text { Lev }_{3}(\mathrm{Bv}) \text { Rel } \\
\end{array}$}} & \multicolumn{2}{|c|}{2007} & \multicolumn{2}{|c|}{2006} & \multicolumn{2}{|c|}{2005} & \multicolumn{2}{|c|}{2004} & \multicolumn{2}{|c|}{2003} \\
\hline & & $\gamma_{0}-\sigma_{U^{*}}^{*}$ & $\gamma_{1}-\sigma_{U}^{*}$ & $\gamma_{0}-\sigma_{\mathrm{U}^{*}}$ & $\gamma_{1}-\sigma_{U^{*}}^{*}$ & $\gamma_{0}-\sigma_{U}^{*}$ & $\gamma_{1}-\sigma_{U}^{*}$ & $\gamma_{0}-\sigma_{U}^{*}$ & $\gamma_{1}-\sigma_{U^{*}}$ & $\gamma_{0}-\sigma_{U^{*}}$ & $\gamma_{1}-\sigma_{U^{*}}$ \\
\hline & 1a & $0.045^{*}$ & $-0.028^{*}$ & $0.044^{*}$ & $-0.027^{*}$ & $0.050 *$ & $-0.031^{*}$ & $0.058^{*}$ & $-0.034^{*}$ & $0.068^{*}$ & $-0.038^{*}$ \\
\hline $\operatorname{Rel} \mathrm{T}_{\mathrm{C}}$ & $2 a$ & 0.035 * & -0.035 * & $0.035 *$ & -0.035 * & $0.039 *$ & -0.038 * & $0.046 *$ & $-0.043 *$ & 0.055 * & $-0.049 *$ \\
\hline$A b s \mathrm{~T}_{\mathrm{C}}$ & $2 a$ & 0.034 * & -0.034 * & $0.034 *$ & -0.032 * & $0.038 *$ & $-0.036^{*}$ & $0.048 *$ & $-0.042 *$ & 0.056 * & -0.050 * \\
\hline $\operatorname{Rel} \mathrm{T}_{\mathrm{C}}$ & $3 \mathbf{a}$ & $0.043^{*}$ & -0.029 * & $0.045^{*}$ & -0.030 * & 0.049 * & $-0.032 *$ & $0.057^{*}$ & $-0.037^{*}$ & 0.067 * & $-0.041^{*}$ \\
\hline$A b s \mathrm{~T}_{\mathrm{C}}$ & $3 a$ & 0.026 * & $-0.045^{*}$ & $0.025 *$ & -0.045 * & $0.028 *$ & -0.051 * & 0.037 * & -0.057 * & $0.046 *$ & $-0.064 *$ \\
\hline \multicolumn{2}{|c|}{ Mean } & 0.037 & -0.034 & 0.037 & -0.034 & 0.041 & -0.038 & 0.049 & -0.043 & 0.058 & $\begin{array}{l}-0.048 \\
\end{array}$ \\
\hline \multicolumn{2}{|c|}{ Median } & 0.035 & -0.034 & 0.035 & -0.032 & 0.039 & -0.036 & 0.048 & -0.042 & 0.056 & -0.049 \\
\hline \multirow{2}{*}{\multicolumn{2}{|c|}{ SD }} & 0.008 & 0.007 & 0.008 & 0.007 & 0.009 & 0.008 & 0.009 & 0.009 & 0.009 & 0.010 \\
\hline & & 0.026 & -0.045 & 0.025 & -0.045 & 0.028 & -0.051 & 0.037 & -0.057 & 0.046 & -0.064 \\
\hline \multicolumn{2}{|c|}{ Max } & 0.045 & -0.028 & 0.045 & -0.027 & 0.05 & -0.031 & 0.058 & -0.034 & 0.068 & -0.038 \\
\hline
\end{tabular}

Notes: Table 3 presents the theoretical and observed regression parameters according to the direct estimation by method 1 for each model using the Relative Lev 3 and Lev 4 financial leverage estimates. The first and second columns in Panel A describe the model and its variables' variants. Each year is divided into three columns. The first one reports the $\sigma_{U}{ }^{*}$ derived by each model and the second and third columns report the observed values of $\gamma_{0}$ and $\gamma_{1}$ in each direct testing. Panel B presents the findings for the null hypothesis H0: $\gamma_{0}=\sigma_{\mathrm{U}}^{*} ; \gamma_{0}=\sigma_{\mathrm{U}^{*}}$. The asterisk * indicates significance $\leq 5 \%$. The sample size $(\mathrm{N})$ is 182 companies.

Table 4. Comparison results by method 2 .

\begin{tabular}{|c|c|c|c|c|c|c|c|c|c|c|c|}
\hline \multicolumn{2}{|c|}{ Panel A } & \multicolumn{2}{|c|}{2007} & \multicolumn{2}{|c|}{2006} & \multicolumn{2}{|c|}{2005} & \multicolumn{2}{|c|}{2004} & \multicolumn{2}{|c|}{2003} \\
\hline \multicolumn{12}{|c|}{ Risk Free Debt Models } \\
\hline \multicolumn{2}{|c|}{$\mathrm{Lev}_{4}(\mathrm{Mv})$ Rel } & Intercept $\gamma_{0}{ }^{*}$ & Slope $\gamma_{1}^{*}$ & Intercept $\gamma_{0}{ }^{*}$ & Slope $\gamma_{1}^{*}$ & Intercept $\gamma_{0}{ }^{*}$ & Slope $\gamma_{1}^{*}$ & Intercept $\gamma_{0}{ }^{*}$ & Slope $\gamma_{1}^{*}$ & Intercept $\gamma_{0}{ }^{*}$ & Slope $\gamma_{1}^{*}$ \\
\hline & 1a & 0.051 & 0.051 & 0.053 & 0.053 & 0.057 & 0.057 & 0.059 & 0.059 & 0.061 & 0.061 \\
\hline $\operatorname{Rel} \mathrm{T}_{\mathrm{C}}$ & $2 a$ & 0.060 & 0.039 & 0.063 & 0.041 & 0.069 & 0.045 & 0.073 & 0.046 & 0.077 & 0.048 \\
\hline$A b s \mathrm{~T}_{\mathrm{C}}$ & $2 a$ & 0.060 & 0.039 & 0.063 & 0.041 & 0.069 & 0.045 & 0.072 & 0.047 & 0.076 & 0.048 \\
\hline $\operatorname{Rel} \mathrm{T}_{\mathrm{C}}$ & $3 a$ & 0.052 & 0.040 & 0.054 & 0.047 & 0.059 & 0.056 & 0.062 & 0.064 & 0.065 & 0.069 \\
\hline$A b s \mathrm{~T}_{\mathrm{C}}$ & $3 a$ & 0.052 & 0.041 & 0.054 & 0.048 & 0.058 & 0.057 & 0.061 & 0.065 & 0.064 & 0.070 \\
\hline \multicolumn{2}{|c|}{ Observed by $\operatorname{Lev}_{4}(\mathrm{Mv}$} & & & & & & & & & & \\
\hline & & 0.077 & 0.019 & 0.082 & 0.021 & 0.093 & 0.022 & 0.101 & 0.022 & 0.108 & 0.022 \\
\hline \multicolumn{2}{|c|}{$\gamma_{0} \gamma_{1}$} & & & & & & & & & & \\
\hline \multicolumn{2}{|c|}{$\mathrm{Lev}_{3}(\mathrm{Bv}) \mathrm{Rel}$} & Intercept $\gamma_{0}{ }^{*}$ & Slope $\gamma_{1}^{*}$ & Intercept $\gamma_{0}{ }^{*}$ & Slope $\gamma_{1}^{*}$ & Intercept $\gamma_{0}{ }^{*}$ & Slope $\gamma_{1}^{*}$ & Intercept $\gamma_{0}{ }^{*}$ & Slope $\gamma_{1}^{*}$ & Intercept $\gamma_{0}{ }^{*}$ & Slope $\gamma_{1}^{*}$ \\
\hline & $1 a$ & 0.036 & 0.036 & 0.039 & 0.039 & 0.044 & 0.044 & 0.046 & 0.046 & 0.048 & 0.048 \\
\hline $\operatorname{Rel} \mathrm{T}_{\mathrm{C}}$ & $2 a$ & 0.046 & 0.030 & 0.050 & 0.032 & 0.057 & 0.037 & 0.060 & 0.038 & 0.063 & 0.040 \\
\hline$A b s \mathrm{~T}_{\mathrm{C}}$ & $2 a$ & 0.046 & 0.030 & 0.049 & 0.032 & 0.056 & 0.037 & 0.059 & 0.039 & 0.063 & 0.040 \\
\hline $\operatorname{Rel} \mathrm{T}_{\mathrm{C}}$ & $3 a$ & 0.037 & 0.055 & 0.040 & 0.061 & 0.046 & 0.069 & 0.049 & 0.077 & 0.051 & 0.082 \\
\hline$A b s \mathrm{~T}_{\mathrm{C}}$ & $3 a$ & 0.053 & 0.039 & 0.057 & 0.044 & 0.065 & 0.050 & 0.069 & 0.057 & 0.073 & 0.061 \\
\hline
\end{tabular}


Table 4. Cont.

\begin{tabular}{|c|c|c|c|c|c|c|c|c|c|c|c|}
\hline \multicolumn{2}{|c|}{ Panel A } & \multicolumn{2}{|c|}{2007} & \multicolumn{2}{|c|}{2006} & \multicolumn{2}{|c|}{2005} & \multicolumn{2}{|c|}{2004} & \multicolumn{2}{|c|}{2003} \\
\hline \multicolumn{12}{|c|}{ Risk Free Debt Models } \\
\hline \multicolumn{2}{|c|}{$\mathrm{Lev}_{4}(\mathrm{Mv}) \mathrm{Rel}$} & Intercept $\gamma_{0}{ }^{*}$ & Slope $\gamma_{1}^{*}$ & Intercept $\gamma_{0}{ }^{*}$ & Slope $\gamma_{1}^{*}$ & Intercept $\gamma_{0}{ }^{*}$ & Slope $\gamma_{1}^{*}$ & Intercept $\gamma_{0}{ }^{*}$ & Slope $\gamma_{1}^{*}$ & Intercept $\gamma_{0}{ }^{*}$ & Slope $\gamma_{1}^{*}$ \\
\hline \multicolumn{12}{|c|}{ Observed by $\operatorname{Lev}_{3}(\mathrm{Bv})$} \\
\hline & & 0.080 & 0.008 & 0.083 & 0.012 & 0.094 & 0.013 & 0.104 & 0.012 & 0.116 & 0.010 \\
\hline \multicolumn{12}{|c|}{$\gamma_{0} \gamma_{1}$} \\
\hline \multicolumn{2}{|c|}{ Panel B } & \multicolumn{2}{|c|}{2007} & \multicolumn{2}{|c|}{2006} & \multicolumn{2}{|c|}{2005} & \multicolumn{2}{|c|}{2004} & \multicolumn{2}{|c|}{2003} \\
\hline \multicolumn{12}{|c|}{ Debt risk free models } \\
\hline \multicolumn{2}{|c|}{$\operatorname{Lev}_{4}(\mathrm{Mv}) \operatorname{Rel}$} & $\gamma_{0}-\gamma_{0}^{*}$ & $\gamma_{1}-\gamma_{1}^{*}$ & $\gamma_{0}-\gamma_{0}^{*}$ & $\gamma_{1}-\gamma_{1}^{*}$ & $\gamma_{0}-\gamma_{0}^{*}$ & $\gamma_{1}-\gamma_{1}^{*}$ & $\gamma_{0}-\gamma_{0}^{*}$ & $\gamma_{1}-\gamma_{1}^{*}$ & $\gamma_{0}-\gamma_{0}^{*}$ & $\gamma_{1}-\gamma_{1}^{*}$ \\
\hline & $1 \mathrm{a}$ & $0.026^{*}$ & $-0.032 *$ & $0.029 *$ & $-0.032 *$ & $0.036^{*}$ & $-0.035 *$ & $0.042 *$ & $-0.037^{*}$ & $0.047 *$ & $-0.039 *$ \\
\hline $\operatorname{Rel} \mathrm{T}_{\mathrm{C}}$ & $2 a$ & 0.017 * & -0.020 * & 0.019 * & -0.020 * & 0.024 * & -0.023 * & 0.028 * & -0.024 * & 0.031 * & -0.026 * \\
\hline Abs $\mathrm{T}_{\mathrm{C}}$ & $2 a$ & $0.017 *$ & $-0.020 *$ & 0.019 * & $-0.020 *$ & $0.024 *$ & $-0.023 *$ & $0.029 *$ & $-0.025 *$ & $0.032 *$ & $-0.026^{*}$ \\
\hline $\operatorname{Rel} \mathrm{T}_{\mathrm{C}}$ & $3 a$ & $0.025 *$ & $-0.021 *$ & 0.028 * & $-0.026 *$ & 0.034 * & -0.034 * & 0.039 * & $-0.042 *$ & $0.043 *$ & $-0.047 *$ \\
\hline$A b s \mathrm{~T}_{\mathrm{C}}$ & $3 a$ & $0.025 *$ & $-0.022 *$ & $0.028 *$ & $-0.027^{*}$ & $0.035 *$ & $-0.035^{*}$ & $0.040 *$ & $-0.043 *$ & $0.044 *$ & $-0.048^{*}$ \\
\hline \multicolumn{2}{|c|}{ Mean } & 0.022 & -0.023 & 0.025 & -0.025 & 0.031 & -0.030 & 0.036 & -0.034 & 0.039 & -0.037 \\
\hline \multicolumn{2}{|c|}{ Median } & 0.025 & -0.021 & 0.028 & -0.026 & 0.034 & -0.034 & 0.039 & -0.037 & 0.043 & -0.039 \\
\hline \multicolumn{2}{|c|}{ SD } & 0.005 & 0.005 & 0.005 & 0.005 & 0.006 & 0.006 & 0.007 & 0.009 & 0.007 & 0.011 \\
\hline \multicolumn{2}{|c|}{ Min } & 0.017 & -0.032 & 0.019 & -0.032 & 0.024 & -0.035 & 0.028 & -0.043 & 0.031 & -0.048 \\
\hline \multicolumn{2}{|c|}{ Max } & 0.026 & -0.020 & 0.029 & -0.020 & 0.036 & -0.023 & 0.042 & -0.024 & 0.047 & -0.026 \\
\hline \multicolumn{2}{|c|}{$\operatorname{Lev}_{3}(\mathrm{Bv}) \mathrm{Rel}$} & $\gamma_{0}-\gamma_{0}^{*}$ & $\gamma_{1}-\gamma_{1}^{*}$ & $\gamma_{0}-\gamma_{0}^{*}$ & $\gamma_{1}-\gamma_{1}^{*}$ & $\gamma_{0}-\gamma_{0}^{*}$ & $\gamma_{1}-\gamma_{1}^{*}$ & $\gamma_{0}-\gamma_{0}^{*}$ & $\gamma_{1}-\gamma_{1}^{*}$ & $\gamma_{0}-\gamma_{0}^{*}$ & $\gamma_{1}-\gamma_{1}^{*}$ \\
\hline & $1 \mathrm{a}$ & $0.044^{*}$ & $-0.028 *$ & 0.044 * & $-0.027 *$ & $0.050 *$ & $-0.031 *$ & $0.058 *$ & $-0.034 *$ & 0.068 * & $-0.038^{*}$ \\
\hline $\operatorname{Rel} \mathrm{T}_{\mathrm{C}}$ & $2 a$ & 0.034 * & $-0.022 *$ & 0.033 * & $-0.020 *$ & 0.037 * & $-0.024 *$ & 0.044 * & $-0.026^{*}$ & 0.053 * & -0.030 * \\
\hline$A b s \mathrm{~T}_{\mathrm{C}}$ & $2 a$ & 0.034 * & $-0.022 *$ & 0.034 * & $-0.020 *$ & $0.038^{*}$ & -0.024 * & 0.045 * & -0.027 * & 0.053 * & -0.030 * \\
\hline $\operatorname{Rel} \mathrm{T}_{\mathrm{C}}$ & $3 a$ & 0.043 * & -0.047 * & 0.043 * & $-0.049 *$ & 0.048 * & $-0.056^{*}$ & 0.055 * & $-0.065 *$ & 0.065 * & $-0.072 *$ \\
\hline$A b s \mathrm{~T}_{\mathrm{C}}$ & $3 a$ & $0.027^{*}$ & $-0.031 *$ & $0.026^{*}$ & $-0.032 *$ & $0.029 *$ & $-0.037^{*}$ & $0.035^{*}$ & $-0.045^{*}$ & $0.043 *$ & $-0.051 *$ \\
\hline \multicolumn{2}{|c|}{ Mean } & 0.036 & -0.030 & 0.036 & -0.030 & 0.040 & -0.034 & 0.047 & -0.039 & 0.056 & -0.044 \\
\hline \multicolumn{2}{|c|}{ Median } & 0.034 & -0.028 & 0.034 & -0.027 & 0.038 & -0.031 & 0.045 & -0.034 & 0.053 & -0.038 \\
\hline \multicolumn{2}{|c|}{ SD } & 0.007 & 0.010 & 0.008 & 0.012 & 0.009 & 0.013 & 0.009 & 0.016 & 0.010 & 0.018 \\
\hline \multirow{2}{*}{\multicolumn{2}{|c|}{$\begin{array}{l}\text { Min } \\
\text { Max }\end{array}$}} & 0.027 & -0.047 & 0.026 & -0.049 & 0.029 & -0.056 & 0.035 & -0.065 & 0.043 & -0.072 \\
\hline & & 0.044 & -0.022 & 0.044 & -0.020 & 0.050 & -0.024 & 0.058 & -0.026 & 0.068 & -0.030 \\
\hline
\end{tabular}

Notes: Table 4 presents the theoretical and observed parameters of $\gamma_{0}$ and $\gamma_{1}$ by method 2 using the Relative Lev $_{3}$ and Lev 4 financial leverage estimates. Panel A presents the theoretical values while Panel B reports the comparison results for the differences between the theoretical and observed parameters. Panel A reports the theoretical $\gamma_{0}{ }^{*}$ and $\gamma_{1}^{*}$ derived by each model and the last row in each group presents the observed parameters of $\gamma_{0}$ and $\gamma_{1}$ based on the estimation of Equation (10), which are the reference parameters for each model. Panel B presents the findings for the null hypothesis H0: $\gamma_{0}=\sigma_{U}^{*} ; \gamma_{0}=\sigma_{U}^{*}$. The asterisk * indicates significance $\leq 5 \%$. The sample size $(\mathrm{N})$ is 182 companies. 
The main results that emerge from Table 2 here imply a positive and significant relationship between $\sigma_{\mathrm{E}}$ and L. This result holds in each case tested: The perfect capital market case (Equation (7)—Model (1a)), corporate taxes only (Equation (8)-Model (2a)), and both corporate and personal taxes (Equation (9)—Model (3a)). Though not reported here, the positive relationship also holds for each of the sample years and for all eight leverage estimates whether the Absolute or Relative method is employed. Note that the overall results tend to support the positive relationship between $\sigma_{\mathrm{E}}$ and $\mathrm{L}$, but the R-squared is higher when using market measures of $\mathrm{L}$ rather than book measures. For the case of a perfect capital market in Table 3, the mean value of R-squared is 0.189 for the Relative $\mathrm{Lev}_{4}$ and 0.110 for its corresponding book measure (Relative $\mathrm{Lev}_{3}$ ). For the corporate tax case, the mean value of R-squared is 0.184 for the Relative $\mathrm{Lev}_{4}$ and 0.103 for its corresponding book measure (Relative $\operatorname{Lev}_{3}$ ). Finally, for the corporate and personal taxes case, the mean value of R-squared is 0.190 for the Relative $\mathrm{Lev}_{4}$ and 0.111 for its corresponding book measure (Relative $\left.\mathrm{Lev}_{3}\right)$. We obtained similar results when the financial leverage is based on long-term debt $\left(\operatorname{Lev}_{1}, \operatorname{Lev}_{2}\right)$ rather than total $\operatorname{debt}\left(\operatorname{Lev}_{3}, \mathrm{Lev}_{4}\right)$. A comparison between the book and market slope regression parameters in each case implies that the extra penalty for volatility with the use of book measures may be more moderate than using market measures. For example, the mean value of the slope measures for the $\mathrm{Lev}_{4}$ across the years is 0.021 (the perfect capital market case), 0.032 (corporate taxes), and 0.022 (both corporate and personal taxes). Similarly, the mean value of the slope measures for $\operatorname{Lev}_{3}$ is 0.011 (the perfect capital market case), 0.016 (corporate taxes), and 0.011 (both corporate and personal taxes).

\subsection{Comparative Analysis and Robustness Tests}

We test the degree to which the observed regression coefficients, $\gamma_{0}$ (intercept) and $\gamma_{1}$ (slope), in each model correspond to their theoretical model counterparts, designated here as $\gamma_{0}{ }^{*}$ and $\gamma_{1}{ }^{*}$. We use two methods to conduct this comparison-method 1 and method 2. In the first method, the corresponding explanatory variables are $[\mathrm{L}],\left[\left(1-\mathrm{T}_{\mathrm{C}}\right) \mathrm{L}\right]$, and $[\mathrm{TL}]$ for the perfect capital market case, the corporate taxes case, and both the corporate and personal taxes, respectively. Thus, in all three cases, the null hypothesis is H0: $\gamma_{0}=\sigma_{U^{*}}$ and $\gamma_{1}=\sigma_{U}{ }^{*}$, where $\sigma_{U}^{*}$ is the theoretical value derived from each model.

In the second method, we first run the following cross-sectional regression model, which is the estimated regression of the perfect capital market case described earlier in Equation (7):

$$
\sigma_{\mathrm{E}}=\gamma_{0}+\gamma_{1}[\mathrm{~L}]
$$

In the first step, we run Equation (11) to estimate the observed $\gamma_{0}$ and $\gamma_{1}$. In the second step, we compare the regression's $\gamma_{0}$ with $\gamma_{0}{ }^{*}$, where $\gamma_{0}{ }^{*}$ is the theoretical value derived from each model and $\gamma_{1}$ to $\gamma_{1}{ }^{*}$ implied in each theoretical model. For the perfect capital market [model (1a)], $\gamma_{0}{ }^{*}=\sigma_{U}$ $=\sigma_{\mathrm{E}} /(1+\mathrm{L})$ and $\gamma_{1}{ }^{*}$ is also $\sigma_{\mathrm{U}}$. For the corporate taxes case [model (2a)] in Equation (8), $\gamma_{0}{ }^{*}=\sigma_{\mathrm{U}}=$ $\sigma_{\mathrm{E}} /\left[1+\left(1-\mathrm{T}_{\mathrm{C}}\right) \mathrm{L}\right]$ and $\gamma_{1}{ }^{*}$ is $\sigma_{\mathrm{U}}\left(1-\mathrm{T}_{\mathrm{C}}\right)$. Finally, for the corporate and personal taxes case [model (3a)] in Equation (9), $\gamma_{0}^{*}=\sigma_{\mathrm{U}}=\sigma_{\mathrm{E}} /[1+\mathrm{TL}]$ and $\gamma_{1}{ }^{*}$ is $\sigma_{\mathrm{U}} \mathrm{T}$. Similarly, we compare the regression $\gamma_{0}$ and $\gamma_{1}$ with the intercept and slope as detailed above.

Table 3 presents the theoretical values derived from each model according to two different measures of $\mathrm{L}$, and the $\mathrm{T}$ tests for $\left[\gamma_{0}-\gamma_{0}^{*}\right]$ and $\left[\gamma_{1}-\gamma_{1}^{*}\right]$ in each year using each $\mathrm{L}$ measure. We mark the $p$-value, which is significant at least at the $5 \%$ level, with an asterisk, *. The last row of each group of models in Table 3 presents the observed parameters $\left(\gamma_{0}\right.$ and $\left.\gamma_{1}\right)$ in the first stage of method 2. Every other row presents the implied theoretical values of the intercept and slope $\left(\gamma_{0}^{*}\right.$ and $\left.\gamma_{1}^{*}\right)$ if the specific model holds true. 
For example, looking at 2006, if model (2a) (the corporate taxes case) holds true, by the null hypothesis (under Relative $\operatorname{Lev}_{4}$ and Relative $\mathrm{T}_{\mathrm{C}}$ ) $\gamma_{0}{ }^{*}$ is 0.063 and $\gamma_{1}^{*}$ is 0.041 . In other words, if model (2a) holds true, the observed parameters in the last row $\left(0.082\right.$ and 0.021 for the intercept $\left(\gamma_{0}\right)$ and slope $\left.\left(\gamma_{1}\right)\right)$ should not be statistically different from their theoretical values above $\left(\gamma_{0}^{*}\right.$ is 0.063 and $\gamma_{1}^{*}$ is 0.021$)$. Since the final results remain the same in all of our financial leverage estimates, we report here the findings using $\operatorname{Lev}_{3}$ and $\mathrm{Lev}_{4}$ only.

We begin by testing the approximation of the observed values relative to their theoretical counterparts using method 1 . This method of comparison relies on the direct testing of each model outlined earlier (that is, (1a), (2a), and (3a)). Note that we test each model directly and then compare the observed parameters $\left(\gamma_{0}\right.$ and $\left.\gamma_{1}\right)$ to the theoretical values $\left(\gamma_{0}{ }^{*}\right.$ and $\left.\gamma_{1}{ }^{*}\right)$ derived from each model. Given that we run the explanatory variables of $L,\left(1-T_{C}\right) L$ and $T L$ directly versus the standard deviation of equity returns, in all cases, both $\gamma_{0}$ and $\gamma_{1}$ should be equal to $\sigma_{U}$, where $\sigma_{U}$ is derived directly from the relevant model. A more detailed explanation is as follows. Equation (12) below is the theoretical model in which debt is risk free, and corporate tax is the only market imperfection (model (2a)):

$$
\sigma_{\mathrm{E}}=\sigma_{\mathrm{U}}+\sigma_{\mathrm{U}}\left[\left(1-\mathrm{T}_{\mathrm{C}}\right) \mathrm{L}\right]
$$

Testing this equation directly means that $\sigma_{\mathrm{E}}$ is the dependent variable, and the term in the squared parentheses, $\left[\left(1-\mathrm{T}_{\mathrm{C}}\right) \mathrm{L}\right]$, is the explanatory variable. Accordingly, the specification model here is Equation (13) below:

$$
\sigma_{\mathrm{E}}=\gamma_{0}+\gamma_{1}\left[\left(1-\mathrm{T}_{\mathrm{C}}\right) \mathrm{L}\right]
$$

Thus, if Model (2a) holds true, then both $\gamma_{0}$ and $\gamma_{1}$ should be equal to $\sigma_{U^{*}}{ }^{*}$ (where $\sigma_{U}$ is derived from the theoretical model in Equation (7)). Hence, we compare the value of $\sigma_{U}^{*}$ with the observed intercept and slope (expressed by $\gamma_{0}$ and $\gamma_{1}$ ) obtained by the direct test we conducted.

Table 3 presents the results of the observed parameters of $\gamma_{0}$ and $\gamma_{1}$ (panel A) using method 1 , and the significance for the $\left[\gamma_{0}-\sigma_{U^{*}}\right]$ and $\left[\gamma_{1}-\sigma_{U^{*}}\right]$ differences (panel B). All of the tests indicate significant gaps for $\left[\gamma_{1}-\sigma_{U^{*}}\right]$ and mostly significant for $\left[\gamma_{0}-\sigma_{U^{*}}\right]$. The gaps are significant for the five years in the sample and for all eight leverage estimates whether the market or book measures are used and whether the Absolute or Relative method is employed for corporate taxes and financial leverage. While the majority of the differences are significant, using market measures generally minimizes the differences between the theoretical and actual values. For example, in 2007, the mean value of $\left[\gamma_{0}-\sigma_{U^{*}}\right]$ is 0.022 using the Relative Lev $_{4}$ and 0.037 using its corresponding book measure-Relative Lev $_{3}$. Similarly, though not reported here, the mean value of $\left[\gamma_{1}-\sigma_{U^{*}}{ }^{*}\right.$ is -0.039 using the Relative $\mathrm{Lev}_{2}$ and -0.043 using its corresponding book measure-Relative Lev $_{1}$. Long term debt measures illustrate similar results. Combining these results with the higher coefficient of determination may suggest that using market measures accords better with the theoretical models.

The results for method 2 presented in Table 4 are similar for the results of method 1 in Table 3. Most the results of the $t$ tests conducted for the differences in the $\left[\gamma_{0}-\gamma_{0}^{*}\right]$ gaps clearly show that the gaps are significant for the five years in the sample and for all leverage estimates whether the Absolute or Relative method is employed. As with the $\left[\gamma_{0}-\gamma_{0}^{*}\right]$ gaps, we find that most of the $\left[\gamma_{1}-\gamma_{1}^{*}\right]$ gaps are significant. Also, the gaps are relatively lower using market rather than book measures of $\mathrm{L}$. For example, in 2006, the mean $\left[\gamma_{0}-\gamma_{0}^{*}\right]$ gap is 0.025 for the market measure compared with 0.036 using the book measure of L. Similarly, the mean $\left[\gamma_{1}-\gamma_{1}^{*}\right]$ gap is 0.025 and 0.030 (in absolute terms) for the market and book measures of $\mathrm{L}$, respectively.

\section{Summary and Conclusions}

This paper contributes to a large body of research on capital structure theory by testing the direct theoretical relationship between the variance of stock returns $\left(\sigma^{2} \mathrm{E}\right)$ and financial leverage $(\mathrm{L})$. The purpose of this study and its motivation was to test the association between $\sigma_{\mathrm{E}}$ and $\mathrm{L}$ when corporate and personal taxes exist. Using a sample of U.S. industrial firms traded on the New York 
Stock Exchange, we provide empirical evidence that the association between $\sigma_{\mathrm{E}}$ and $\mathrm{L}$ is affected by the level of corporate and personal level taxes.

The main findings of this research are as follows. First, $\sigma_{\mathrm{E}}$ was positively related to financial leverage in all sample years tested, and this positive relationship was robust regardless of whether financial leverage was measured in book or market terms, and whether the tax estimates were based on Relative or Absolute methods of measurement. Second, the relationship between $\sigma_{\mathrm{E}}$ and $\mathrm{L}$ was positive in all of the three theoretical models tested here: The perfect capital market, corporate tax model, and both corporate and personal tax model. Finally, using market measures generated better results in terms of $\mathrm{R}$ squared, and reduced the differences between the theoretical and actual parameters. These results might support and motivate the use of market measures of financial leverage rather than book measures.

Our study contributes to the existing literature in the following aspects: First, our research tested three theoretical models in the context of the $\sigma \mathrm{E}-\mathrm{L}$ relationship, and in this respect it extends prior studies. Second, for all of these three models, we compared the OLS regression coefficients with their theoretical counterparts and examined whether the differences between these values were statistically significant-an important investigation that has not been conducted so far in the literature. In addition, to test whether the $\sigma \mathrm{E}-\mathrm{L}$ relationship is positive, an attempt was also made to capture the degree to which the theoretical models were practically confirmed. Third, as emphasized earlier in this study, most prior studies only employed a standard regression analysis of the relationship between $\sigma_{\mathrm{E}}$ and $\mathrm{L}$ and some other variables, conducting what we call here the indirect-test approach. Furthermore, taxes were excluded from these tested regressions. Our study, in contrast, was entirely devoted to testing the theoretical relationship between $\sigma_{\mathrm{E}}$ and $\mathrm{L}$-adopting what we call in this study the direct-test approach. In addition, we employed direct estimates of the additional variables that are present in the theoretical models, such as corporate and personal taxes, as well as both book and market leverage measures.

The comprehensive approach employed in this study may enhance the understanding of the nature of the theoretical relationship between $\sigma_{\mathrm{E}}$ and $\mathrm{L}$ when both corporate and personal taxes exist, and may help comprehend the degree to which this theoretical relationship is confirmed in the real corporate world.

One limitation of this study, which may also be an opportunity for future research, is the incorporation of risk in addition to risk free debt. Future study should involve an estimation of the " $\operatorname{cov}\left(\mathrm{K}_{\mathrm{U}}, \mathrm{r}\right)$ " term, which will likely need an intensive data search, and the employment of methodological assumptions.

Author Contributions: The authors contributed equally to the paper in the context of research design, gathering data, empirical design and testing procedures as well as in writing the paper.

Funding: This research received no external funding.

Acknowledgments: We would like to thank the seminar participants at the University of Haifa for their comments and suggestions on an earlier draft of the paper. Remaining errors are our responsibility.

Conflicts of Interest: The authors declare no conflict of interests.

\section{Appendix A Summary of Financial Leverage Proxies}

The table indicates the type of financial leverage from which the proxy was derived and the specific paper that obtained these proxies. Further information about the construction of the specific variable appears in the comments column. 
Table A1. Summary of Literature Financial Leverage Proxies.

\begin{tabular}{|c|c|c|}
\hline Authors & Proxy for Financial Leverage & Comments \\
\hline \multirow{2}{*}{ Faff et al. (2002, NAJE) } & Total Liabilities/Total Equity & $\begin{array}{c}\text { Equity and preferred stock are } \\
\text { measured as market values, } \\
\text { whereas liabilities are measured } \\
\text { as book values }\end{array}$ \\
\hline & $\begin{array}{l}\text { (Total Liabilities + Preferred } \\
\text { Stock)/Total Equity }\end{array}$ & $\begin{array}{c}\text { Equity and preferred stock are } \\
\text { measured as market values, } \\
\text { whereas liabilities are measured as } \\
\text { book values }\end{array}$ \\
\hline Ghosh and Jain (2000, JCF) & $\begin{array}{l}\text { (LTD + Current Liabilities)/(book value } \\
\text { of debt + market value of equity) }\end{array}$ & Ghosh and Jain (2000, JCF) \\
\hline Lang et al. (1996, JFE) & $\begin{array}{c}\text { (Short term debt }+ \text { Long term } \\
\text { debt)/total assets }\end{array}$ & $\begin{array}{c}\text { They used only book values rather } \\
\text { than market values }\end{array}$ \\
\hline Bradley et al.(1984, JF) & LTD/(LTD + Total EQUITY) & $\begin{array}{l}\text { LTD-book value, } \\
\text { equity-market value }\end{array}$ \\
\hline \multirow{2}{*}{ Bowman $(1980$, JAR) } & \multirow{2}{*}{$\begin{array}{l}\text { Four variations of book and } \\
\text { market values }\end{array}$} & $\begin{array}{l}\text { Equity is common stockholders' } \\
\text { equity. Debt is equal to total assets } \\
\text { minus common } \\
\text { stockholders' equity }\end{array}$ \\
\hline & & $\begin{array}{l}\text { Market value of common } \\
\text { stockholders' equity is calculated } \\
\text { by the market value per share of } \\
\text { common stock times the number } \\
\text { of common shares outstanding }\end{array}$ \\
\hline \multirow[t]{2}{*}{ Breen and Lerner $(1973, \mathrm{JF})$} & LTD/Common Equity & $\begin{array}{l}\text { Ratio of only long term debt to } \\
\text { common equity, the second } \\
\text { measure of total debt to equity } \\
\text { showed similar results and is not } \\
\text { reported }\end{array}$ \\
\hline & Total Debt/Common Equity & Book values \\
\hline Rosenberg and McKibben (1973, JF) & Senior Securities/total assets & $\begin{array}{l}\text { Based on Book valuesCalculated } \\
\text { as a 5-year average }\end{array}$ \\
\hline Errunza $(1979$, FM) & Total Debt/Total Assets & \\
\hline \multirow[t]{2}{*}{ Beaver et al. (1970, AR) } & $\begin{array}{l}\text { Total Senior Securities including current } \\
\text { liabilities/Total Assets }\end{array}$ & \\
\hline & LTD/Total Assets & \\
\hline
\end{tabular}

\section{References}

Ait-Sahalia, Yacine, Jianqing Fan, and Yingying Li. 2013. The leverage effect puzzle: Disentangling sources of bias at high frequency. Journal of Financial Economics 109: 224-49. [CrossRef]

Arena, Matteo P., and Andrew H. Roper. 2010. The effect of taxes on multinational debt location. Journal of Corporate Finance 16: 637-54. [CrossRef]

Barclay, Michael J., Clifford W. Smith Jr., and Erwan Morellec. 2006. On the debt capacity of growth options. Journal of Business 79: 37-58. [CrossRef]

Beaver, William, Paul Kettler, and Myron Scholes. 1970. The association between market determined and accounting determined risk measures. The Accounting Review 45: 654-82.

Black, F. 1976. Studies of Stock Market Volatility Changes. Paper Presented at the American Statistical Association, Business and Economic Statistics Section, American Statistical Association, Washington DC, WA, USA. pp. 177-81. Available online: http:/ / www.citeulike.org/group/2384/article/7656400 (accessed on 6 March 2019).

Bollerslev, Tim, Natalia Sizova, and George Tauchen. 2012. Volatility in equilibrium: A symmetries and dynamic dependencies. Review of Finance 16: 31-80. [CrossRef]

Bowman, Robert G. 1980. The importance of a market-value measurement of debt in assessing leverage. Journal of Accounting Research 18: 242-54. [CrossRef] 
Butler, Kirt C., Rosanne M. Mohr, and Richard R. Simonds. 1991. The Hamada and Conine Leverage Adjustments and the Estimation of Systematic Risk for Multisegment Firms. Journal of Business Finance and Accounting 18: 885-901. [CrossRef]

Bradley, Michael, Gregg A. Jarrell, and E. Han Kim. 1984. On the existence of an optimal capital structure: Theory and evidence. The Journal of Finance 39: 857-78. [CrossRef]

Breen, William J., and Eugene M. Lerner. 1973. Corporate financial strategies and market measures of risk and return. The Journal of Finance 28: 339-51. [CrossRef]

Cheung, Yin-Wong, and Lilian K. Ng. 1992. Stock price dynamics and firm size: An empirical investigation. Journal of Finance 47: 1985-97. [CrossRef]

Christie, Andrew A. 1982. The stochastic behavior of common stock variances: Value, leverage and interest rate effects. Journal of financial Economics 10: 407-32. [CrossRef]

DeAngelo, Harry, Linda DeAngelo, and Toni M. Whited. 2011. Capital structure dynamics and transitory debt. Journal of Financial Economics 99: 235-61. [CrossRef]

Dhaliwal, Dan, Shane Heitzman, and Oliver Zhen Li. 2006. Taxes, leverage, and the cost of equity capital. Journal of Accounting Research 44: 691-723. [CrossRef]

Duffee, Gregory R. 1995. Stock returns and volatility: A firm-level analysis. Journal of Financial Economics 37: 399-420. [CrossRef]

Dyreng, Scott D., Michelle Hanlon, and Edward L. Maydew. 2010. The effects of executives on corporate tax avoidance. The Accounting Review 85: 1163-89. [CrossRef]

Errunza, Vihang R. 1979. Determinants of financial structure in the central American common market. Financial Management 8: 72-77. [CrossRef]

Fama, Eugene F., and Kenneth R. French. 2002. Testing Tradeoff and Pecking Order Predictions about Dividends and Debt. Review of Financial Studies 15: 1-33. [CrossRef]

Faff, Robert W., Robert D. Brooks, and Ho Yew Kee. 2002. New evidence on the impact of financial leverage on beta risk: A time-series approach. The North American Journal of Economics and Finance 13: 1-20. [CrossRef]

Fan, Joseph P. H., Sheridan Titman, and Garry Twite. 2012. An International Comparison of Capital Structure and Debt Maturity Choices. Journal of Financial and Quantitative Analysis 47: 23-56. [CrossRef]

Figlewski, Stephen, and Xiaozu Wang. 2000. Is the Leverage Effect a Leverage Effect? Working Paper. New York: Stern School of Business, New York University.

Ghosh, Aloke, and Prem C. Jain. 2000. Financial leverage changes associated with corporate mergers. Journal of Corporate Finance 6: 377-402. [CrossRef]

Graham, John. 1999. Do personal taxes affect corporate financing decisions. Journal of Public Economics 73: 147-85. [CrossRef]

Graham, John R, and Campbell R Harvey. 2001. The theory and practice of corporate finance: Evidence from the field. Journal of Financial Economics 60: 187-243. [CrossRef]

Kemsley, Deen, and Doron Nissim. 2002. Valuation of the debt-tax shield. Journal of Finance 57: 2045-73. [CrossRef]

Lang, Larry, Eli Ofek, and RenéM Stulz. 1996. Leverage, investment, and firm growth. Journal of financial Economics 40: 3-29. [CrossRef]

Lemmon, Michael L., Michael R. Roberts, and Jaime F. Zender. 2008. Back to the beginning: Persistence and the cross-section of corporate capital structure. Journal of Finance 63: 1575-608. [CrossRef]

Marston, Felicia, and Susan Perry. 1996. Implied Penalties for Financial Leverage: Theory versus Empirical Evidence. Quarterly Journal of Business and Economics 35: 77-97.

Miller, Merton H. 1977. Debt and taxes. Journal of Finance 32: 261-75.

Modigliani, Franco, and Merton H. Miller. 1958. The Cost of Capital, Corporation Finance and the Theory of Investment. The American Economic Review 48: 261-97.

Modigliani, Franco, and Merton H. Miller. 1963. Corporate income taxes and the cost of capital: A correction. The American Economic Review 53: 433-43.

Rosenberg, Barr, and Walt McKibben. 1973. The prediction of systematic and specific risk in common stocks. Journal of Financial and Quantitative Analysis 8: 317-33. [CrossRef]

Schwert, G. William. 1990. Stock Volatility and the Crash of 87. The Review of Financial Studies 3: 77-102. [CrossRef]

Titman, Sheridan, and Roberto Wessels. 1988. The determinants of capital structure choice. Journal of Finance 43: 1-19. [CrossRef] 
Van Binsbergen, Jules H., John R. Graham, and Jie Yang. 2010. The cost of debt. Journal of Finance 65: 2089-136. [CrossRef]

Welch, Ivo. 2004. Capital Structure and Stock Returns. Journal of Political Economy 112: 106-31. [CrossRef] Yagil, Joe. 1982. On valuation, beta, and the cost of equity capital: A note. The Journal of Financial and Quantitative Analysis 17: 441-49. [CrossRef] 